M. Giamboni • K. Ustaszewski • S. M. Schmid •

M. E. Schumacher $\cdot$ A. Wetzel

\title{
Plio-Pleistocene transpressional reactivation of Paleozoic and Paleogene structures in the Rhine-Bresse transform zone (northern Switzerland and eastern France)
}

Received: 13 June 2003 / Accepted: 14 November 2003 / Published online: 5 February 2004

(C) Springer-Verlag 2004

\begin{abstract}
Pliocene to recent uplift and shortening in the southern Rhinegraben is documented by deformation of Pliocene fluvial gravels, deposited on a nearly planar surface, as well as by progressive deflection and capture of rivers. This deformation is suggested to result from thick-skinned tectonic movements as evidenced by observations on seismic records, which demonstrate a spatial coincidence between en-échelon anticlines at the surface and faults located in the crystalline basement. These findings contradict the often invoked thin-skinned tectonism in the recent tectonic history of the Rhinegraben. In particular the transfer zone between the Rhinegraben and the Bressegraben is very suitable for reactivation under the present day stress field. Thickskinned reactivation of faults in the basement is also expressed by focal plane mechanisms of recent earthquakes showing strike-slip- rather than reverse faulting characteristics. This is of importance for the densely populated and industrialised southern Rhinegraben, previously affected by large earthquakes in historical times (e.g. Basel 1356).
\end{abstract}

Keywords Neotectonics · Fault reactivation - Southern Rhinegraben · Tectonic geomorphology · Geophysics

\footnotetext{
M. Giamboni ( $)$ K. Ustaszewski · S. M. Schmid ·

M. E. Schumacher · A. Wetzel

Geologisch-Paläontologisches Institut,

Universität Basel,

Bernoullistrasse 32, 4056 Basel, Switzerland

e-mail: marzio.giamboni@buwal.admin.ch

Tel.: +41-31-3247103

Fax: $+41-31-3230348$

Present address:

M. Giamboni, Bundesamt für Umwelt, Wald und Landschaft, GIS Fachstelle,

3003 Bern, Switzerland
}

\section{Introduction}

Hitherto, only limited efforts have been undertaken to relate the neotectonic activity of the Rhinegraben area to its structural configuration and the present stress field (e.g. Illies and Greiner 1979; Meyer et al. 1994; Schumacher 2002). The analysis of intraplate tectonics and pre-existing crustal discontinuities implies a high potential of fault reactivation (e.g. Laubscher 1992; Ziegler et al. 1995) that could induce earthquakes (e.g. Meyer et al. 1994; Deichmann et al. 2000). Therefore, it is desirable to relate the neotectonic deformation of the Rhinegraben area, which hosts major industrial and population centres, to its structural framework in order to determine which faults are most likely to move again within the short term.

The Basel area (Fig. 1), situated at the boundary between the Jura and the southern Rhinegraben, was shaken in historical times by several of the strongest earthquakes that occurred in NW Europe. Moreover, this area represents an ideal place for studying the reactivation of pre-existing crustal discontinuities as it is made up of several tectonic structures of different age, the older controlling the evolution of the younger (Fig. 1). The different tectonic stages, which shaped the area, are well documented, owing to the excellent database provided by many generations of geologists (Laubscher 2001, and references therein).

The "classic" interpretation of the Basel area distinguishes between three main phases of tectonism during the Cenozoic (e.g. Buxtorf and Koch 1920; Fischer 1965; Liniger 1967; Laubscher 1987). The first one was related to subsidence during Oligocene rifting and led to the formation of the Rhinegraben.

A second phase, Early Neogene in age, was accompanied by major stress field changes and caused the cessation of rifting in the southernmost Rhine Graben, as well as widespread uplift. During a third phase, Mio- to Pliocene in age, the area of the entire Jura Mountains became affected by Alpine orogeny: the classical thinskinned Jura thrust-and-fold belt developed. 
However, a fourth phase of tectonic activity during the Plio-Pleistocene is evident in an area north of the thinskinned Jura belt. Previously, some authors (Erzinger 1943; Liniger 1967) recognised structures within the Tabular Jura and the adjacent Rhinegraben that formed after main Jura folding. They were often referred to as "Plio-Pleistocene subsidence". Despite this very important "pioneer work", the kinematics of this activity remained enigmatic.

A growing number of studies provides evidence for such a fourth phase of uplift and shortening in the southernmost Rhinegraben, in a zone linking the Bressegraben with the Rhinegraben (Fig. 1), which post-dated the formation of the thin-skinned Jura belt (Meyer et al. 1994; Nivière and Winter 2000; Fabbri et al. 2001; Ustaszewski et al. 2001; Laubscher 2001; Giamboni et al. 2003). However, there are contrasting ideas about the kinematic framework of this youngest episode, as shall be discussed in the following sections.

To elucidate the Cenozoic history of the southernmost Rhinegraben - the Ajoie area and around Montbéliard (Fig. 1) -we used field and borehole data, reflection seismic lines, geoelectric logs and data from geomorpho- logical mapping and DEM analysis. In addition to the three generally accepted tectonic episodes described above, we provide new evidence for the nature and kinematics of the recently identified fourth one. This youngest episode follows pre-existing normal faults and flexures of Eo-/Oligocene age and reflects thick-skinned inversion of basement faults. Deformation of Pliocene sediments, as well as changes in the drainage system due to uplift, suggest that this stage of tectonic activity persists from Pliocene to recent.

\section{Geological and tectonic framework}

The study area is located in NW Switzerland west of Basel (Ajoie) and in northerly adjacent France. There, the southern part of the Rhinegraben is juxtaposed against the Tabular Jura and the northernmost Folded Jura (Fig. 1). The southern part of the Rhinegraben represents a hilly landscape with altitudes between $400 \mathrm{~m}$ in the south and $250 \mathrm{~m}$ in the north. At its south-western and western margin the Rhinegraben is surrounded by the Tabular Jura, which is topographically higher, but of humble

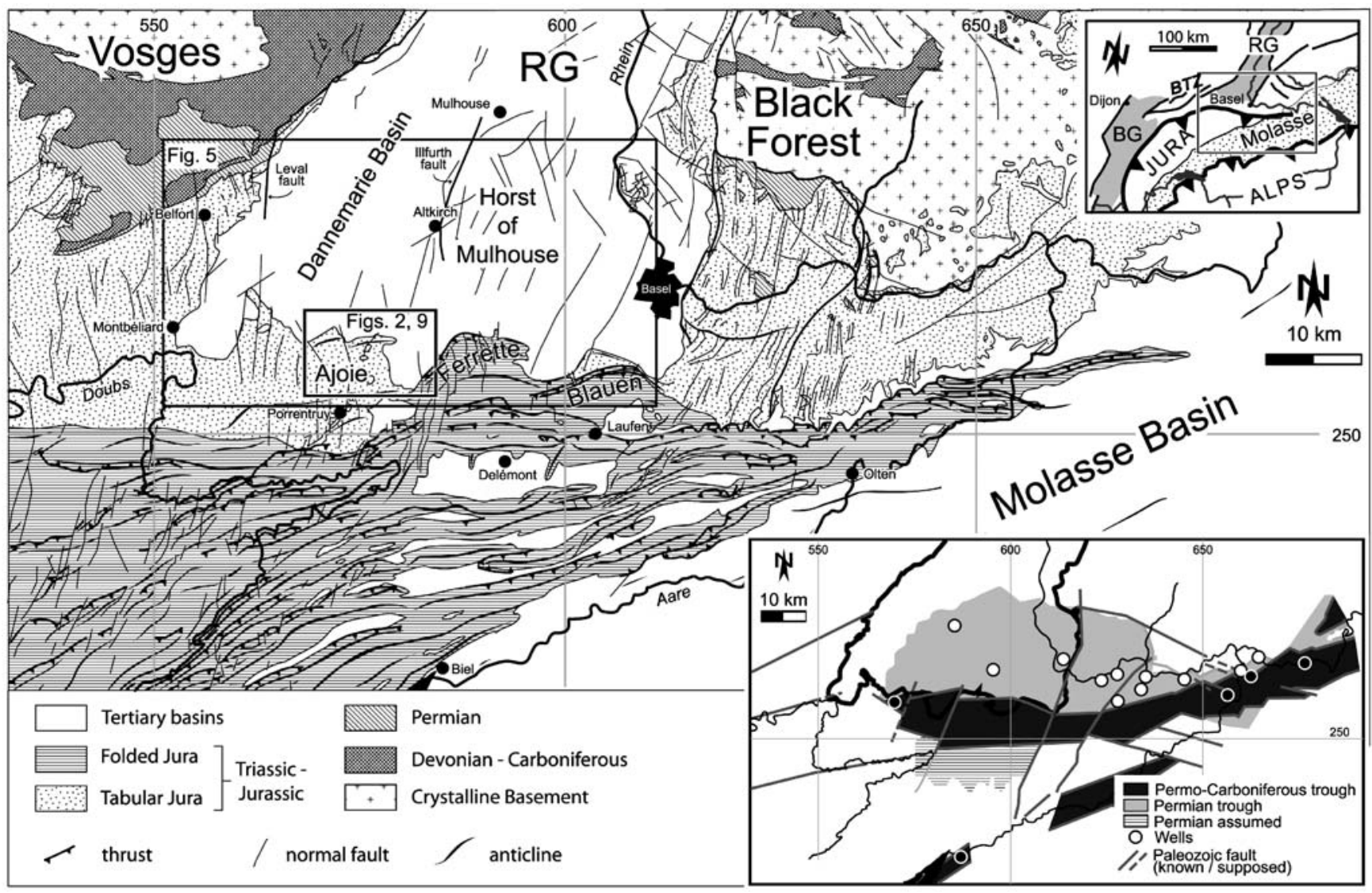

Fig. 1 Structural sketch map of the southern Rhinegraben and surrounding areas (redrawn after Fischer 1969). Inset in the upper right: Regional sketch map showing the tectonic setting of the southern Rhinegraben in the northern Alpine foreland. Shaded: Cenozoic rift basins; dotted: Alpine Molasse; $R G$ Rhinegraben; $B G$
Bressegraben; BTZ Rhine-Bresse Transform Zone. Inset in the lower right: Permo-Carboniferous troughs (redrawn and modified after Allenbach 2003). Eastwards the Northern Swiss PermoCarboniferous trough connects with the Constance trough. Numbers on the map's edges are Swiss National coordinates 


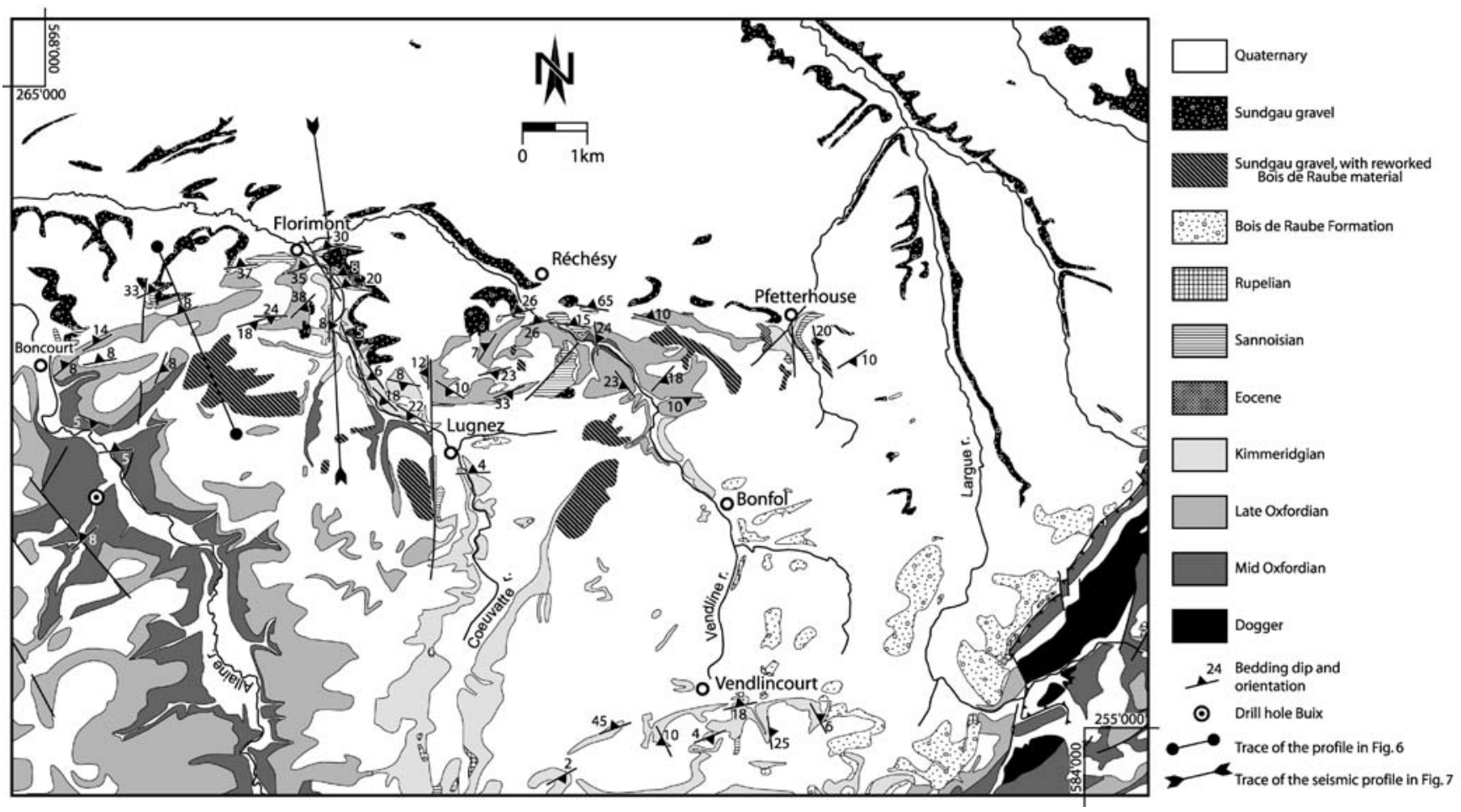

Fig. 2 Geological map of the northern Ajoie (modified after Liniger 1970). Traces of the cross section (Fig. 6) and the reflection seismic line (Fig. 7) are shown

relief. This rather flat relief is only disturbed by three small arcuate hills located at the junction between the Rhinegraben and the Tabular Jura. These hills correspond to the Vendlincourt, Réchésy and Florimont anticlines, which very gently fold this part of the Tabular Jura (Fig. 2). The highest elevations in the area are the southerly and easterly adjacent folds of the Folded Jura, i.e. the Ferrette and the Blauen anticlines (Fig. 1). Mesozoic and Tertiary sediments cover most of the area, and are in turn overlain by Pleistocene loess. Outcrops are rare.

\section{Permo-Carboniferous troughs of northern Switzerland}

A reflection seismic and drilling campaign by the NAGRA (Swiss National Cooperative for Storage of Nuclear Waste) led to the discovery of a conspicuous Late Paleozoic trough system in the subsurface of northern Switzerland, spanning from Lake Constance to Basel (e.g. Diebold 1990; Thury et al. 1994). This basin system extends further to the west into the area investigated in our study (bottom right insert in Fig. 1; Matter 1987; Diebold and Naef 1990; Philippe 1995; Krohe 1996; Diebold and Noack 1997; Laubscher and Noack 1997; Pfiffner et al. 1997).

This trough system developed in response to PostVariscan transtensional tectonics and consists of a system of mostly WSW-ENE striking, narrow and elongated fault-bounded grabens, whose orientation follows the structural grain of the Variscan belt (Ziegler 1990b). Therein, up to several hundreds of meters of continental clastic sediments of Permian and Carboniferous age accumulated (Diebold et al. 1992). The history of these intramontane troughs ended in Late Permian times, as evidenced by the unconformably overlying, Early Triassic Buntsandstein formation.

\section{Mesozoic subsidence}

The Middle Anisian regional transgression (Muschelkalk) marks the first marine deposits in the area (Ziegler 1990a). During the Middle and Late Triassic, carbonates, intercalated with marls, and evaporites formed under shallow-marine to epicontinental conditions. The latter (Anhydritgruppe, Gipskeuper) provided the principal décollement horizons during Mio-/Pliocene Jura thin skinned thrusting (Laubscher 1961; Jordan and Nüesch 1989). During the Jurassic, marine conditions prevailed. Until recently, it was thought that this period was one of tectonic quiescence except for uniform thermal subsidence (Ziegler 1990a). However, recent sedimentological studies (Gonzales 1996; Allia 1996; Burkhalter 1996; Allenbach 2001, 2002, 2003; Wetzel et al. 2002) suggest reactivation of Late Paleozoic faults already during the Mesozoic, resulting in small-scale thickness and facies changes. 
Fig. 3 Stratigraphic table for Cenozoic sediments in the southern Upper Rhinegraben and adjacent Tabular Jura and Jura Mountains (based on Sissingh 1998; Berger 2000) Tectonic events compiled from various sources, paleo-stress after Schumacher (2002). (See text for details)

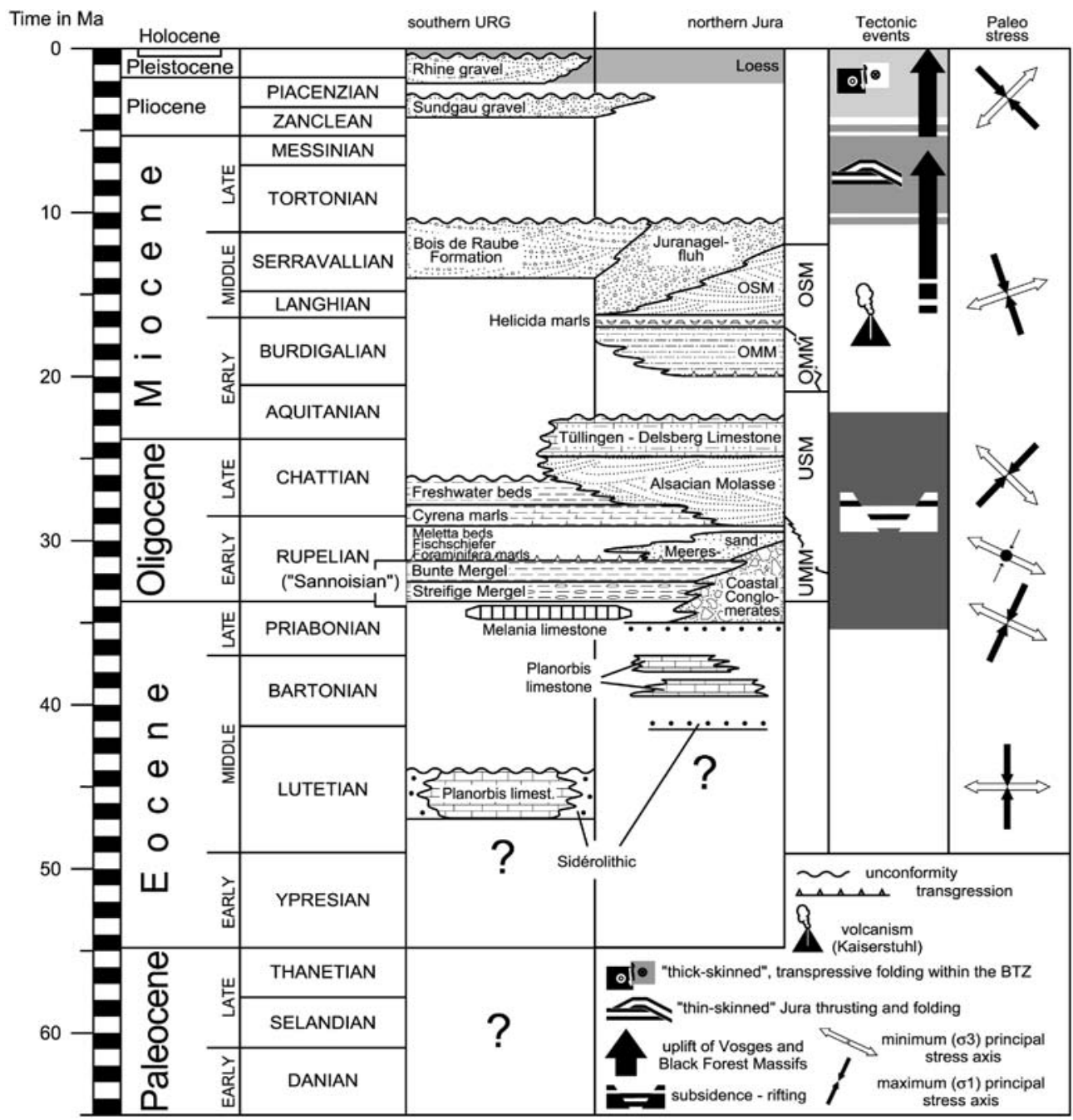

The oldest Mesozoic sediments outcropping in the study area are oolithic platform carbonates of MidJurassic age (Dogger), exposed in the cores of the Ferrette and Blauen anticlines (Ruhland and Blanat 1973; BitterliBrunner et al. 1984). Shallow platform carbonates and neritic deposits of Oxfordian to Kimmeridgian age are the youngest Mesozoic sediments preserved. They are exposed along the Allaine, Coeuvatte and Vendline valleys in the Tabular Jura of the Ajoie (Fig. 2).

\section{Cenozoic rifting}

The N-NE-trending Bresse- and Rhinegraben form the central segments of the European Cenozoic rift system (Fig. 1). Rifting initiated in Late Eocene times and persisted until the Early Miocene (e.g. Pflug 1982; Bergerat et al. 1990). The sinistral Rhine-Bresse Transform Zone linked the two graben structures (Laubscher 1970; Rat 1978; Bergerat and Chorowicz 1981; Fig. 1) and nucleated along reactivated faults, related to the Permo-Carboniferous graben system (Laubscher 1986; Ziegler 1992; Schumacher 2002).
During the first phase of rifting shallow grabens and half grabens as well as slight flexures formed at the eastern and southern border of the southern Rhinegraben (Laubscher 1982). Particularly the Dannemarie basin, bounded by the Illfurth fault in the east, by the Leval fault in the west (Fig. 1) and by the flexures of Florimont and Réchésy in the south (Fig. 2), started to subside (Laubscher 1982). While lacustrine marls and anhydrite/ halite accumulated in the Mulhouse and Dannemarie basins (Doebl 1970; Sissingh 1998), fresh- to brackishwater carbonates (Melania limestone; Fig. 3) were deposited on the horst of Mulhouse (Sittler 1972; Sissingh 1998). Coarse conglomerates formed along the graben margins in response to an increasing relief and erosion of the rift flanks. This style of sedimentation persisted until the Lower Rupelian (Duringer 1988). In the study area, the conglomerates are well exposed at the eastern side of the Ferrette anticline and along the northern border of the Tabular Jura in the Ajoie. During the Lower Rupelian a brackish-marine environment established (Blue Marls/ Streifige and Bunte Mergel, Brianza et al. 1983; Sissingh 1998). Marine sedimentation dominated until the Late Rupelian (Doebl and Teichmüller 1979) and the "Meer- 
essand", "Foraminifera Marl", "Fish Marl", and "Meletta Clay" formations accumulated (Fig. 3, Fischer 1965; Duringer 1988). During the Middle Chattian, sedimentation again became brackish ("Cyrenea Marls" formation) and finally fluvio-lacustrine ("Alsacian Molasse" formation, Fischer 1965). Middle Chattian Freshwater beds (including "Tüllinger Süsswasserkalke") formed in a system of lakes, during a period when connections to the marine realm were interrupted at both graben ends (Sissingh 1998).

During Aquitanian times, erosion and uplift in the area of the future Jura Mountains took place (Laubscher 1992, 2001). An angular unconformity formed between the Chattian to Lower Aquitanian Delsberg carbonates and the shallow marine Burdigalian sediments (transgression of the Upper Marine Molasse, OMM in Fig. 3; Buxtorf 1901; Koch 1923).

Renewed uplift started near the Burdigalian/Langhian boundary and led to tilting and erosion of the Burdigalian shallow marine beds (Laubscher and Noack 1997). In the course of this tectonic event, enhanced uplift of the Vosges and Black Forest massifs (Laubscher 1992, 2001) led to an evolving relief. Associated southward flowing rivers shed conglomerates deriving from the Vosges (Bois de Raube Formation; Kälin 1997) and the Black Forest (Juranagelfluh; Kälin 1993). Several tens of meters of predominantly coarse clastics were deposited in canyonlike channels (Kälin 1997; Laubscher 2001), extending far southward into the Tertiary basins of Laufen, Delémont and Porrentruy (Fig. 1).

\section{Miocene Jura folding}

During Serravallian times the Alpine thrust front started to propagate further northward and influenced-by longrange effects - the area of the present-day Jura Mountains: The Molasse basin, with its Mesozoic substrate, was detached along décollement horizons within Triassic evaporites. Initially only the southernmost parts of the Jura Mountains were incorporated into a deforming thinskinned wedge of sediments situated in front of the effectively rigid Molasse basin. About 10.5 Ma ago (end of deposition of the Bois de Raube Formation, Kälin 1997) the southernmost part of the Rhinegraben area (i.e. the present-day Delémont and Laufen Tertiary basins, Fig. 1) also became involved in Jura folding, which lasted until 3.4 Ma before present (Bolliger et al. 1993; Kälin 1997). The time span of Jura folding itself is characterised by a lack of sedimentation.

While the location of the northern edge of the thinskinned wedge is well constrained east of Basel (boundary between Folded and Tabular Jura) and again in the southern Ajoie (Mt. Terri thrust), it is only poorly constrained in the area of the Ferrette and Blauen chains southwest of Basel.

\section{Deposition of the Pliocene "Sundgau gravel"}

A new episode of fluvial deposition, forming the so-called "Sundgau gravel" in the southern Rhinegraben and northern Tabular Jura (Ajoie), started in the Early Pliocene (around $4 \mathrm{Ma}$ ). These gravels consist of up to $70 \%$ of clasts eroded from the Alps and the Molasse basin (Liniger 1967). Bonvalot (1974) demonstrated that the "Sundgau gravel" represents the up-stream equivalent of the Pliocene "Cailloutis de Desnes" and "Sables de Neublans" formations in the northern Bressegraben. Rodent and mollusc assemblages provided a Late Zanclean to Piacenzian age (4.2-2.9 Ma) for these formations (see Petit et al. 1996; Fejfar et al. 1998). Thus, even if the deposition of the earliest portions of the "Sundgau gravel" temporally overlaps with a late stage of thin-skinned Jura folding, it still partly postdates it.

The paleo-drainage system in the Central Alps and their northern foreland changed significantly during the Zanclean: In the Early Pliocene Alpine drainage across the Swiss Molasse plain was first flowing eastward into the paleo-Danube river (Fig. 4a, Liniger 1966, 1967; Petit et al. 1996). The upper course of this paleo-Danube approximately corresponded to the catchment area of the present-day Aare and Rhône rivers. Hence, this system was referred to as "Aare-Danube" system by Liniger (1966). Enhanced subsidence in the Bressegraben during Early Pliocene times (Fig. 4 b, Rat 1978) caused an increment of headward erosion from the west, resulting in the capture of the paleo-Aare by the paleo-Doubs River during the Upper Zanclean (at 4.2 Ma, Petit et al. 1996; Fejfar et al. 1998). Furthermore, persisting uplift in the south-eastern Black Forest induced a decoupling of the paleo-Aare from the paleo-Danube. As a result, the paleoAare river flowed around the eastern tip of the Jura Mountains and passed through the southern part of the Rhinegraben into the Bressegraben. This river deposited the "Sundgau gravel" (Fig. 4 b).

During Piacenzian and Quaternary times, the Bressegraben underwent renewed uplift and was subjected to erosion (Sissingh 1998). Meanwhile, the southern and northern segments of the Rhinegraben underwent further subsidence (e.g. Doebl 1970; Schumacher 2002). Thereby, the paleo-Aare was captured once more and started to flow northward into the Rhinegraben (Fig. 4c) (Liniger 1966; Petit et al. 1996; Giamboni et al. 2003). Up to $200 \mathrm{~m}$ of Alpine gravel were deposited during the Pleistocene in the Rhine valley north of Basel.

\section{Structural evidence for Middle Pliocene to recent tectonics}

Most authors accept late Mio- to Pliocene Jura-folding as thin-skinned. It is not clear, however, if this episode of thin-skinned Jura folding persists until present. Recently, Nivière and Winter (2000) have proposed that the thinskinned Jura Mountains have already propagated further north into the area of the southernmost Rhine Graben, 

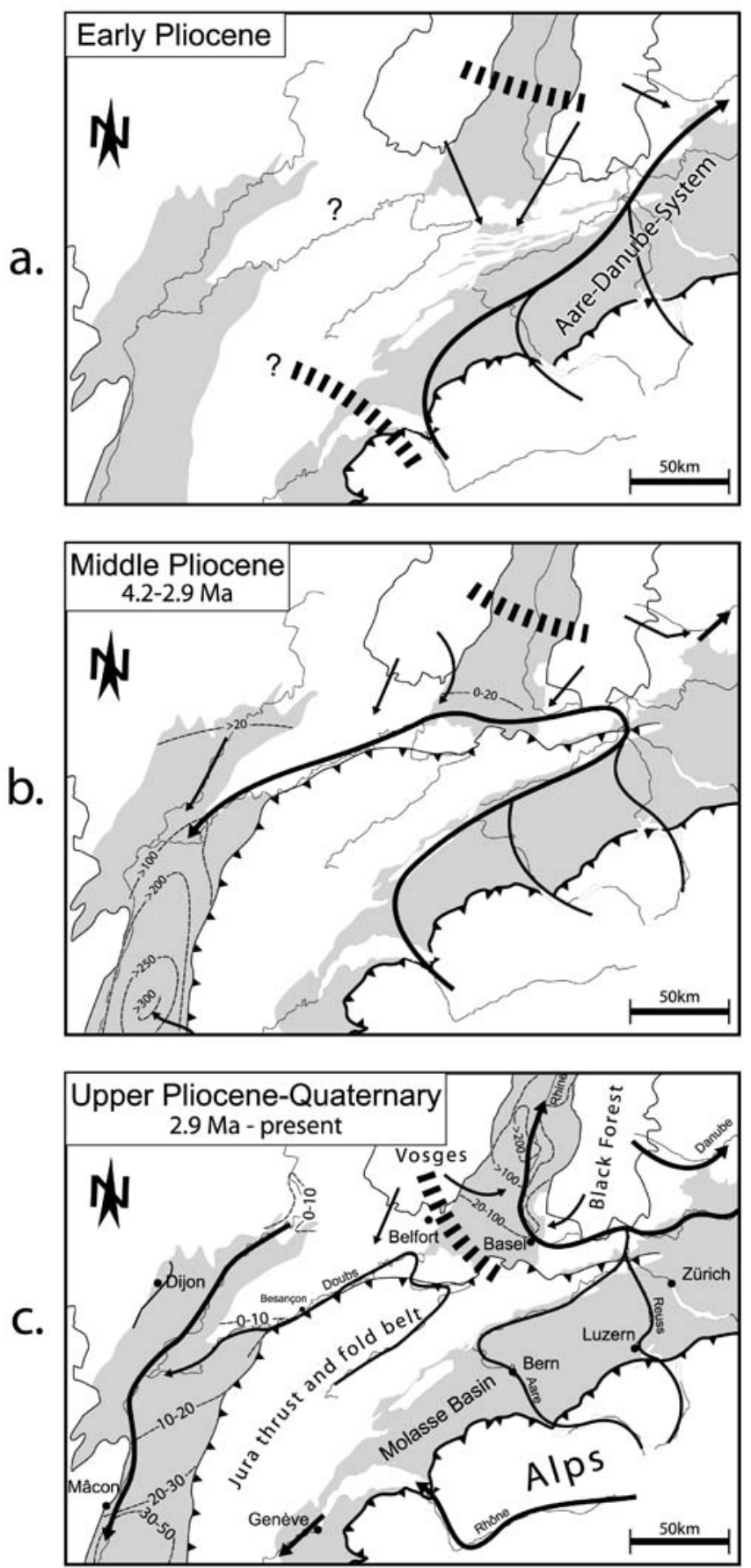

Fig. 4 Major changes in the paleohydrographic pattern in the north-western Alpine foreland since Miocene times (modified after Liniger 1966; Petit et al. 1996). Ages (rodent chronozones) given by Petit et al. (1996), updated after Fejfar et al. (1998). Thin dashed lines represent isopachs (in meters) of the Pliocene and Quaternary sediments for the Bressegraben (after Debrand-Passard and Courbouleix 1984) and for the Rhinegraben (after Doebl 1970). Thick dashed lines are major water divides

detached above Triassic evaporitic layers. On the other hand, there might have been a change towards a thickskinned style of deformation (e.g. Meyer et al. 1994), or, alternatively, active shortening in the Alpine foreland may have given way to a combined strike-slip and normal faulting mode of deformation, as suggested by seismotectonic evidence (Deichmann et al. 2000). The different proposed kinematic scenarios do not necessarily contradict each other, since the stress field in the region is known to be decoupled between sedimentary cover and its basement (Müller et al. 1987, 2001). The "Sundgau gravel" plays a crucial role to answer some of these questions.

\section{The "Sundgau gravel" base map}

The Pliocene "Sundgau gravel" (2.9-4.2 Ma) was deposited by a shallow braided river, having a shifting network of unstable, low-sinuosity channels (Miall 1996). Depth of the channels was of the order of $1 \mathrm{~m}$. The deposits are dominated by clast-supported, crudely bedded longitudinal bedforms and lag deposits, as well as transverse bedforms with planar cross-beds. Thin sandy, bar-top sheets are formed at bar margins by surface runoff. According to Schumm (1985), the slope of such low sinuosity braided rivers is in the order of 1.5 to $2.0 \%$.

These sedimentological characteristics strongly support the assumption that the base of the "Sundgau gravel" Formation formed on a nearly planar and horizontal surface. Therefore, this planar surface represents an ideal marker horizon to record post Middle Pliocene differential vertical displacements due to folding and/or faulting.

The "Sundgau gravel" is exposed within a $20-\mathrm{km}$ wide, E-W striking belt, delimited to the east by the Rhine river valley and to the west by the entrance into the narrow Doubs valley near Montbéliard (Fig. 5). The eastern parts of this gravel formation were eroded by the Rhine River during the Pleistocene and no remnants were found further upstream so far. Downstream and in the Doubs valley a few alluvial terraces of the Sundgau gravel system are preserved (Contini et al. 1973). Southeastward, the "Sundgau gravel" nestles the Ferrette anticline, and overlaps the northernmost part of Tabular Jura in the Ajoie (Fig. 5). North of the latitude of Dannemarie-Altkirch, a lateral transition from the "Sundgau gravel" to the Pliocene gravel and sands of the paleoAare tributaries from the Vosges Mountains, was observed (Théobald et al. 1976; Ménillet et al. 1989). The gravel thickness ranges from a few meters up to $30 \mathrm{~m}$.

Théobald (1934) made a first attempt to reconstruct the "Sundgau gravel" base. In contrast to the present study, he did not take into account the southernmost outcrops in the northern Tabular Jura. Théobald's gravel base map shows increasing amounts of uplift from NW (near Dannemarie) to SE (i.e. towards the Ferrette anticline). He attributed the tilt of the gravel base to a wide-ranging uplift of the Tabular and Folded Jura after deposition of the "Sundgau gravel".

The "Sundgau gravel" base map presented in this study (Fig. 5) was constrained by borehole data, geological maps and field observations. In the eastern, southern and westernmost valleys of the area the base is in contact to 


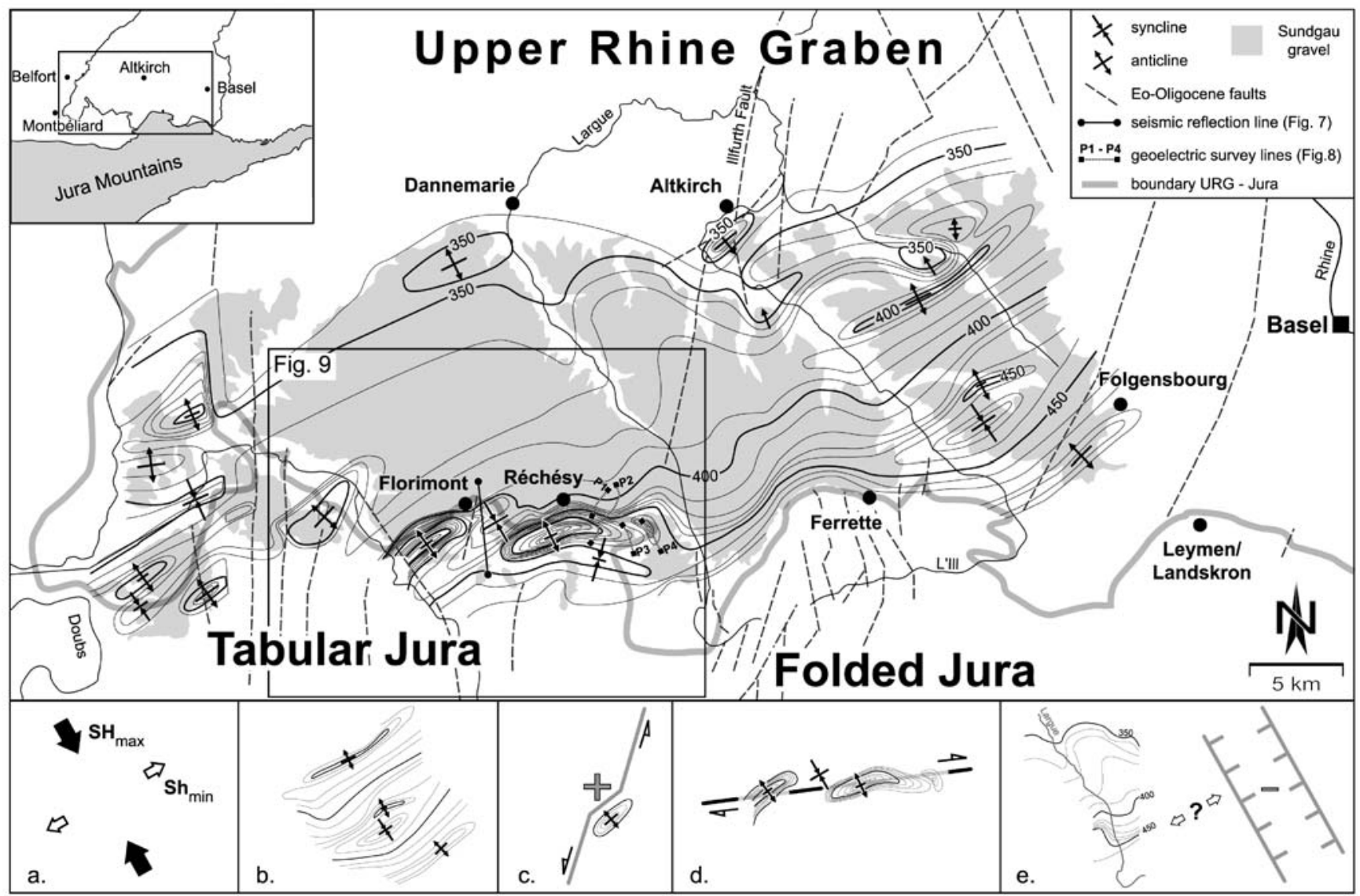

Fig. 5 Base map of the Pliocene "Sundgau gravel"; iso-lines are labelled in meters above sea level; traces of the reflection seismic line (Fig. 7) and the geo-electric survey lines (Fig. 8) are shown.

the underlying Oligocene or Jurassic beds and is well constrained by field and well data. The central part south of Dannemarie, however, shows considerable lack of information, because rivers incise only into the "Sundgau gravel" beds. Furthermore, no subcrop data are available from this area.

Contouring revealed a system of more than ten narrow folds with predominantly SW-NE-trending and laterally plunging fold axes. The syn- and anticlines largely correspond to topographic depressions and highs, respectively, except at places where they are eroded by antecedent rivers. Even the different fold amplitudes exhibit a general conformability with the topographic structures. The area with the highest relief (up to $550 \mathrm{~m}$ ), i.e. the northern Ajoie, exhibits the most accentuated anticlines with the largest amplitudes (90 and $120 \mathrm{~m})$. In contrast, folds with small amplitudes (10-20 m), such as those west of Folgensbourg, south of Dannemarie or in the south-westernmost area near Montbéliard, correspond to a gentle, slightly undulating relief. A further significant feature visible on the map is the general rise of the "Sundgau gravel" base from north to south. This, and the accentuated rise at the northern rim of the Ferrette
Bottom inserts a to e: detail regions of the map put into viable kinematic scenarios within the recent stress field. "+" and "-" depict uplift and subsidence, respectively. Refer to text for details

anticline, conforms to the geometry of the Folded Jura front at this place.

Some of the minor undulations in the gravel's base (e.g. in the area W of Folgensbourg or S of Dannemarie) might correspond to the progressive filling of a not exactly planar surface. However, the alignment of folds observed in the gravel's base is highly systematic throughout the contoured area. This strongly suggests that their origin is indeed related to tectonic processes. In the following, we want to discuss some of these isohypse map features in the context of a viable kinematic framework (Fig. 5, bottom inserts a to e), which is in concordance with the recent regional stress field (Fig. 5a) as derived from earthquake focal mechanisms (Plenefisch and Bonjer 1997) and in-situ-stress measurements (Becker 2000; Häring 2001). The fold trends and the strike of the general southward rise of the gravel's base (exemplified in Fig. 5b) are exactly perpendicular to the recent maximum horizontal stress SHmax. Under such conditions, Rhine Graben faults (like the Illfurth fault, see Figs. 1 and 5) can be reactivated as sinistral wrench faults. Immediately S of Altkirch, a small anticline has formed precisely where the Illfurth fault is kinked. This feature is interpreted as a restraining bend (Fig. 5c). The two en- 


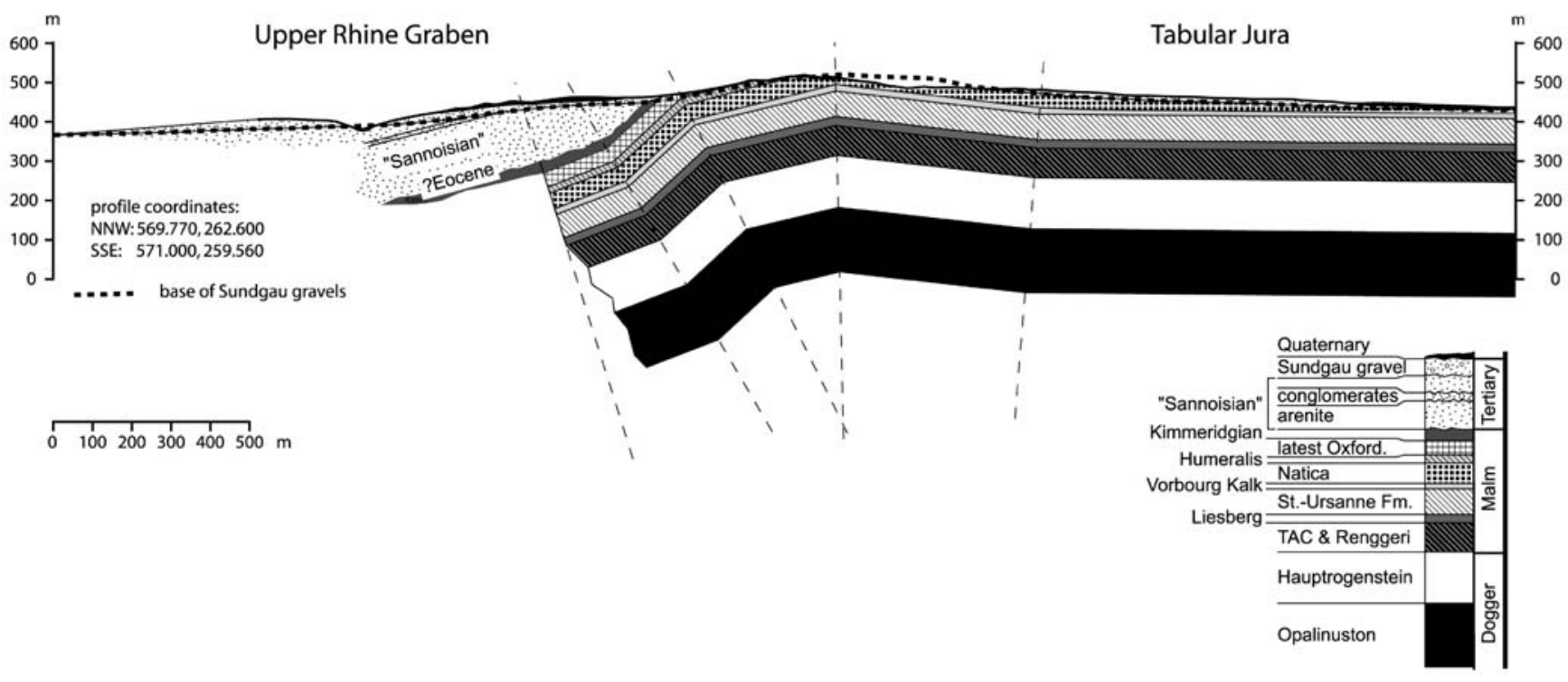

Fig. 6 Geological section across the Florimont anticline (based on data from Liniger 1970 and Figs. 2 and 5). Geology in the northern part of the section is poorly constrained due to the lack of outcrop and subcrop data. Note the close correlation between topographic

échelon aligned anticlines with the greatest amplitude (90 and $120 \mathrm{~m}$ ) formed at the place of compressively or transpressively reactivated extensional flexures, which are situated above ENE-oriented basement faults related to the Paleozoic trough system (Fig. 5d). Finally, the "southstepping" isohypses in the valleys dissecting the "Sundgau gravel" base (particularly pronounced in the Largue valley), as well as the trend of the valleys themselves are oriented perpendicular to Shmin. This suggests that minor normal faults, developing parallel to SHmax, may have affected the Pliocene cover (Fig. 5e).

The base of the "Sundgau gravel" (Fig. 5) thus undoubtedly indicates a young (post $2.9 \mathrm{Ma}$ ) tectonic episode that postdates "classical" Jura folding (10.5 to 3.4 Ma; Kälin 1997). In the following section, we will focus on two major anticlines situated at the border between the northern Ajoie and the southern Rhinegraben (Figs. 2, 5).

\section{Anticlines of Réchésy and Florimont}

\section{Geological data}

Two folds delimit the boundary between the Folded Jura and south-western Rhinegraben in the northern Ajoie area: the Florimont and Réchésy anticlines (Fig. 2), that were studied by previous authors (Hummel 1914; Théobald 1934; Erzinger 1943; Liniger 1964, 1967). Hummel (1914) and Liniger $(1964,1967)$ postulated a polyphase history of these structures, beginning with an extensional flexure related to the opening of the Rhinegraben in crest, maximum elevation of folded Pliocene sediments and hinge line of the folded Mesozoic substratum. The "Sundgau gravel" unconformably overlies Paleogene and Mesozoic strata. For location see Fig. 2

Eo-Oligocene times, followed by Mio-Pliocene folding. Liniger (1967) argued for three phases of Mio-Pliocene folding: (1) after the deposition of the "Hipparion sands" of Serravallian age (corresponding to the Lower Ajoie Member of the Bois de Raube Formation), (2) after the deposition of the "Vogesenschotter" (Upper Ajoie Member of the Bois de Raube Formation, dated as Upper Serravallian to Lower Tortonian) and (3) after the deposition of the "Sundgau gravel" (ages after Kälin 1997, see also Fig. 3). He also proposed compressive reactivation of faults, which root in the basement. Their activity was suggested to be combined with further northward propagation of décollement in the Triassic evaporitic layers, i.e. from the former Jura front, situated south of Porrentruy, towards the E-W-striking Oligocene flexures which delimit the Rhinegraben area to the south (Liniger 1967, Fig. 1).

The strongly curved fold axes of these two perianticlines plunge slightly to either sides-the Allaine valley in the west and the Coeuvatte valley in the east (Fig. 2) - and hence, display an en-échelon alignment (Berner 2001). The WSW-ENE trending Florimont anticline, located to the west, has a relatively steep dipping northern and a gently dipping southern limb (see crosssection in Fig. 6). The anticlines are separated from each other by a NNW-striking strike-slip fault that accommodated the simultaneous formation of both anticlines. The Réchésy anticline to the east is subdivided into two different segments: a western and WSW-ENE-trending one and an eastern, roughly $\mathrm{E}-\mathrm{W}$-trending one. The western segment depicts a nearly symmetrical hinge with moderately dipping limbs, whereas the eastern segment 
Fig. 7 Reflection seismic profile across the Florimont and Réchésy structures (data courtesy of Shell International EP). a Un-migrated and stacked time section. b Interpreted section: $T$ Lower Rupelian marls onlapping onto flexure; $A$ Top Malm; $D$ Top Dogger; $L$ Top Liassic; $M$ Top Muschelkalk formation; $B M$ unconformity at the base of the Mesozoic; cross-hatched faulted zone associated with the late Paleozoic trough border faults. Base of the Pliocene Sundgau gravel, derived from the contours given in Fig. 5, as well as the topography are superimposed onto the topmost part of the figure. The vertical scale in meters is chosen such as to coincide with that of the reflection seismic line. According to the two-way-travel-times of seismic waves (derived from the borehole Buix, see Fig. 2 for location), $1 \mathrm{~s}$ TWT equals ca. $1,500 \mathrm{~m}$ depth), hence vertical exaggeration is by a factor of 1.26. For location see Figs. 2 and 5
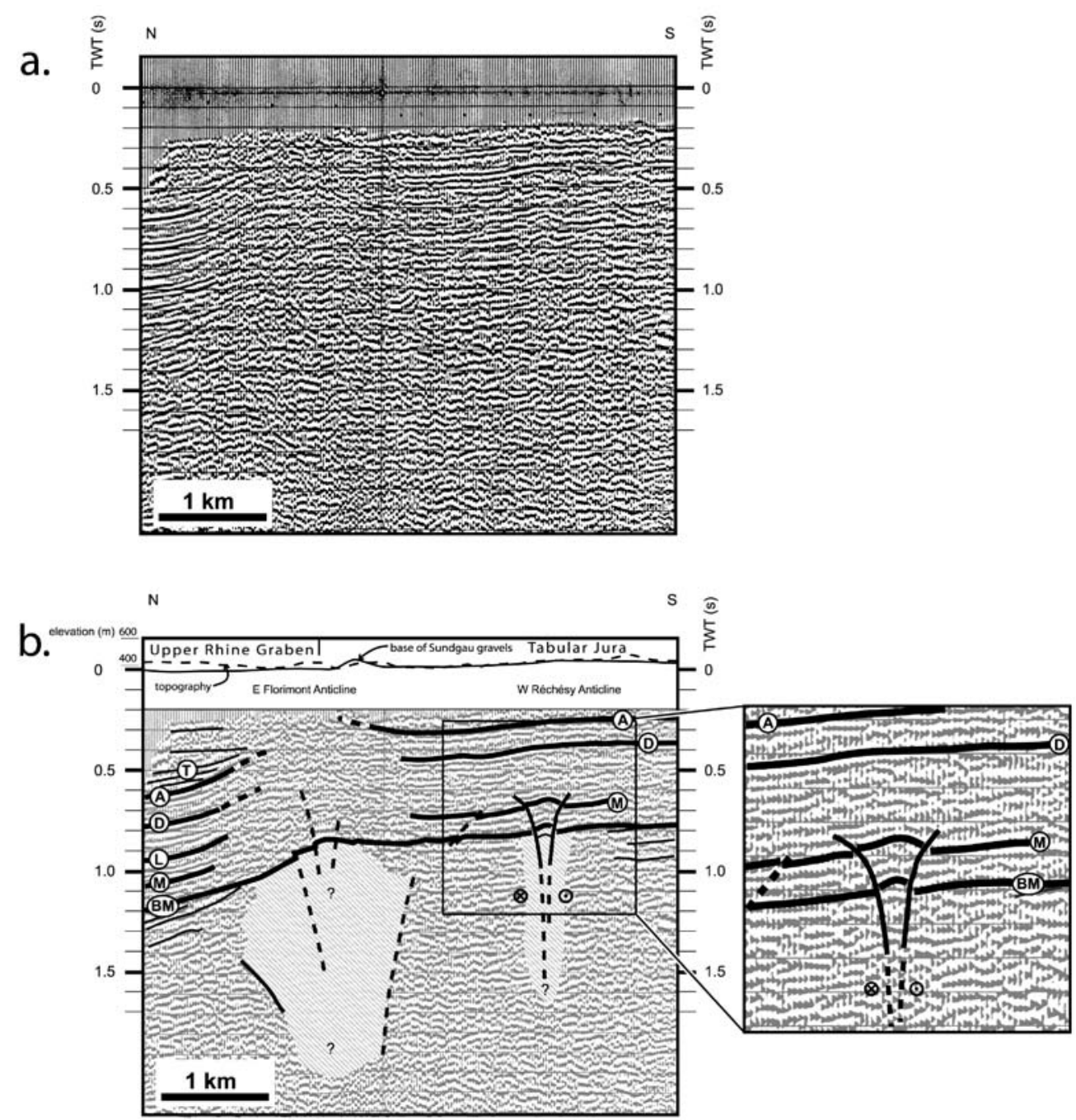

shows an asymmetry with a steeper northern limb (Fig. 2), as it is the case for the Florimont anticline (Fig. 6).

There, the steep dip of strata in the northern part (Fig. 6) is predominantly the result of extensional flexuring. This can be inferred from the onlap geometry of Early Oligocene synrift sediments, discernible on seismic profiles (Fig. 7, see below). The gently dipping southern limb, on the other hand, can be clearly attributed to a later episode of shortening: a closer look at the base of the "Sundgau gravel" (which unconformably overlie both synrift and Mesozoic sediments) reveals that their maximum elevation is located precisely above the hinge of the Mesozoic sediments. This spatial coincidence strongly suggests that the southern limb was formed after the deposition of the "Sundgau gravel" (Fig. 6). However, an embryonic fold may have already existed prior to the deposition of the gravel-this is evidenced by the slightly higher dip angle in the Mesozoic substratum with respect to the gravel.
Seismic data

Reflection seismic records provide detailed insight into the internal structure of the anticlines. Figure 7 shows a $\mathrm{N}-\mathrm{S}$-trending industry reflection seismic profile, situated at the border between the Rhinegraben's southernmost end and the adjacent Tabular Jura (see Figs. 2 and 5 for location). It crosses the en-échelon-aligned Florimont and Réchésy anticlines across their eastern and western ends, respectively. Diagnostic seismic reflectors were identified in a nearby borehole (located in Fig. 2). Additionally, the base of the Sundgau gravels (as inferred from Fig. 5) has been projected into the topmost part of Fig. 7. Note, however, that the resolution of the seismic profile (on the order of a few tens of metres) does not permit an identification of the gravel's base.

The section displays an asymmetric anticline with two angular unconformities. During a first stage of deformation, i.e. during opening of the Rhinegraben, an extensional flexure deformed the Mesozoic sediments (BM to A). Onlap of Tertiary strata (T) onto this flexure are interpreted as the sedimentary response to extension and 

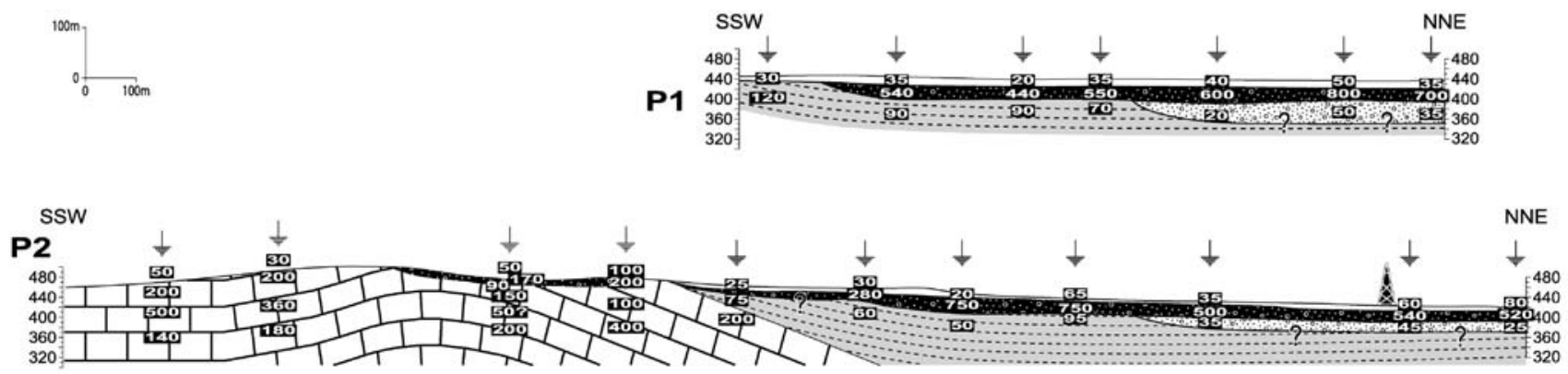
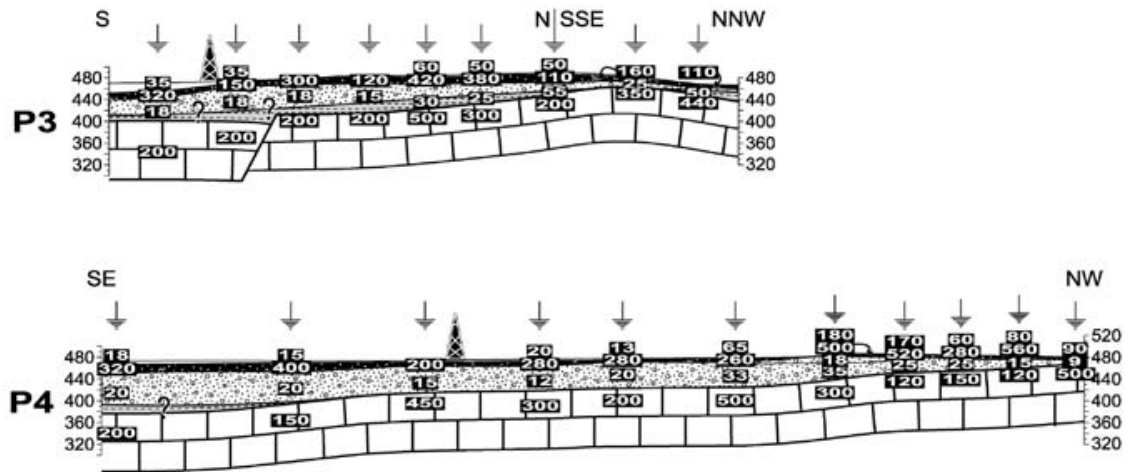

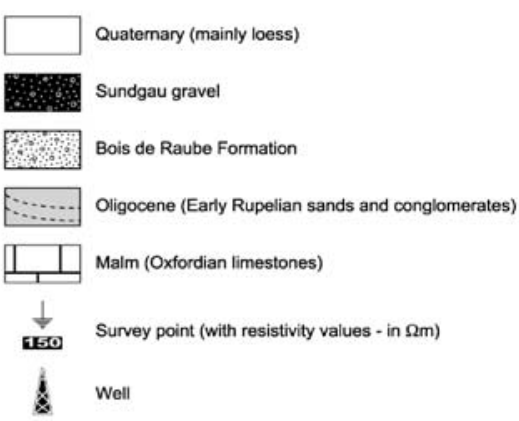

Fig. 8 Interpreted geoelectric survey lines (measurements provided by the Institut für geowissenschaftliche Gemeinschaftsaufgaben at Hanover, courtesy of Mr. P. Elsass, BRGM Alsace). Interpretation of the logs is based on the base map of the Sundgau gravel, results of the reflection seismic interpretation, the geological map and complemented by additional field data. For position of sections (P1-P4) see Fig. 5

tors are identical across this part of the section, strongly suggesting a linked origin.

By tracing these gentle culminations down into deeper strata, a pronounced up-warping within Triassic to Liassic strata can be recognised (Fig. 7, right inset). We interpret the up-warping of the Sundgau gravel and underlying strata to be related to the formation of a positive flower structure. The up-warped Mesozoic reflectors are clearly seen to emanate from rather diffuse fault zones situated within the Permo-Carboniferous "basement" (note the extensively disturbed reflectors in Fig. 7). The location of two such fault zones, precisely beneath the crests of both anticlines, hints towards a reactivation of pre-existing faults delineating the Paleozoic graben system (Fig. 1). In the Mesozoic to Cenozoic cover this reactivation caused further shortening of the formerly extensional flexures. This folding has produced the southern and gentle limbs of the two anticlines, and steepened the northern limbs, which coincide with the pre-existing flexure. Since, this folding has also affected the Pliocene sediments, it hence postdates them at least partly.

\section{Geoelectric data}

Geoelectric resistivity surveys allow detailed insights into shallow subsurface structures of parts of the eastern Réchésy anticline. The measured resistivity values along four profiles (Fig. 8), trending SW-NE and SE-NW, 
respectively (for location see Fig. 5), were interpreted by using additional information from borehole, field and reflection seismic data. Profiles P2 and P3 (Fig. 8) include the crest of the Réchésy anticline while profiles P1 and P4 are situated in the northern and southern limb of this anticline, respectively.

Three major unconformities could be identified. A first one, the angular unconformity between the Jurassic bedrock (Resistivity values $[\rho]=120-500 \Omega \mathrm{m}$ ) and the Oligocene deposits $([\rho]=25-120 \Omega \mathrm{m})$ has already been described and is visible on the geological cross-section of the Florimont anticline (Fig. 6) as well as on the seismic profile (Fig. 7). The two younger unconformities, at the bases of the Miocene deposits (Bois de Raube Formation) and the "Sundgau gravel" respectively, are characterised by a rather gentle discordance north of the anticlines (Fig. 8, P1 and P2). The angular unconformity increases towards the crest and the southern limb of the anticline (Fig. 8, P3 and P4).

The base of the second unconformity (Miocene) is made up by fluviatile gravel and sands shed from the Vosges Mountains (Bois de Raube Formation) and characterised by $[\rho]=15-50 \Omega \mathrm{m}$. This Miocene formation often overlies Oligocene sediments, but locally rests on Jurassic bedrocks (Fig. 8, P3 and P4). North of the Réchésy anticline, i.e. within the southern Rhinegraben, the Miocene strata beneath the base "Sundgau gravel" erosional unconformity are sub-horizontally bedded (Fig. 8, P1 and P2). At the eastern end of the gently plunging anticline, Miocene deposits are preserved over the entire structure and they extend southwards from the crest (Fig. 8, P3 and P4). Note that the Miocene sediment outcrops are confined in an area between the western Ferrette anticline to the east, the Réchésy anticline to the NW and the Vendlincourt anticline to the SW (Fig. 2) in the northern Ajoie. This area probably corresponds to one of the main southward flowing Miocene river channel systems (Liniger 1967; Kälin 1993). Since these Miocene series are warped up near the anticline, syn- and/or postdepositional differential uplift has to be inferred (see discussion below).

The third unconformity is marked by the base of the Pliocene "Sundgau gravel" ( $[\rho]=110-800 \Omega \mathrm{m})$, as the E-W-trending paleo-Aare formed an at least locally flat surface (see above). This is confirmed by the observation that its deposits discordantly overlie Jurassic, Oligocene or Miocene strata, as clearly shown by the geoelectric resistivity surveys (Fig. 8). The geoelectric logs also provide independent evidence that the "Sundgau gravel" was differentially uplifted after its deposition (Fig. 8, P2, $\mathrm{P} 3$ and $\mathrm{P} 4$; compare with data provided in the base map of Fig. 5). A paleo-channel, situated in the fold crest, depicts a difference in altitude of about $30 \mathrm{~m}$ with respect to the base of the "Sundgau gravel" north of the anticline (Fig. 8, P2). Note that the "Sundgau gravel" found on the northern limb of the Réchésy anticline are incised into the Oligocene deposits, whereas their southernmost extent is truncated due to erosion (Fig. 8, P1 and P2). Hence, crest and southern limb of the Réchésy anticline have been eroded since the deposition of the Sundgau gravel, while erosional unconformities are preserved further north and within the southernmost Rhinegraben area.

\section{Tectonically induced young uplift inferred from the drainage pattern}

Erosion and deposition on the one hand, and growth of active structures on the other, modify a relief, evolving from ongoing tectonic activity. Drainage systems adapt to changes in surface slope and thus potentially record information about the evolution of faults and folds (e.g. Seeber and Gornitz 1983; Schumm 1986; Keller and Pinter 2002). These concepts were applied to the relief and drainage systems associated with the Réchésy, the Florimont and the Vendlincourt anticlines (see Fig. 9 and their location in Fig. 1).

The Réchésy anticline represents the structure with the largest structural and topographic amplitude in the study area. The drainage divide (Fig. 9b) clearly follows the fold crest and the local drainage system precisely mirrors structure and symmetry of the anticline. Streams formed during or after fold formation and flow perpendicular to the drainage divide and the structural contours, as derived from the folded former plain (Fig. 5). A hint of a former radial organisation of the local drainage pattern around the plunging nose of the anticline is still visible at its western termination. There, the radial patterns are disturbed by a longitudinal river in the south, which flowed parallel to the evolving structure, and by the transverse Coeuvatte River in the west (Fig. 9). This river flows perpendicular to the fold and gathers the catchment areas of the radial streams. Further east, the Réchésy anticline is cut by the valley of the antecedent Vendline River, which is fairly deeply entrenched in a gorge. Two prominent wind gaps appear $500 \mathrm{~m}$ and 2,500 $\mathrm{m}$ west of the Vendline valley; such gaps are too wide and too deep to have result from the conjunction of regressive erosion of rills north and south of the Réchésy anticline. They most simply mark the former course of a stream that crossed what is now the water divide (Profile A-A' in Fig. 9a and c). These broad and presently dry open valleys were formerly occupied by the Vendline River, their highest parts now being situated about $40 \mathrm{~m}$ and $100 \mathrm{~m}$ above the present-day Vendline valley floor. A further wind gap occurs at the western end of the anticline (Profile A-A' in Fig. 9c). This wind gap clearly represents an old course of a river, which formerly crossed the culmination of the present-day anticline axis in a gorge at this point and is now $60 \mathrm{~m}$ above the present-day Coeuvatte valley floor. As a consequence of folding, the gorge has been abandoned and the river was deflected around the plunging western nose of the anticline (Fig. 9). About $250 \mathrm{~m}$ further north and on the northern limb of the anticline, a dry valley (Fig. 9a, marked by an open circle) shows at least three levels of in-boxed erosional terraces. This tributary valley represents a hanging valley, which was captured and truncated by the present-day Coeuvatte 


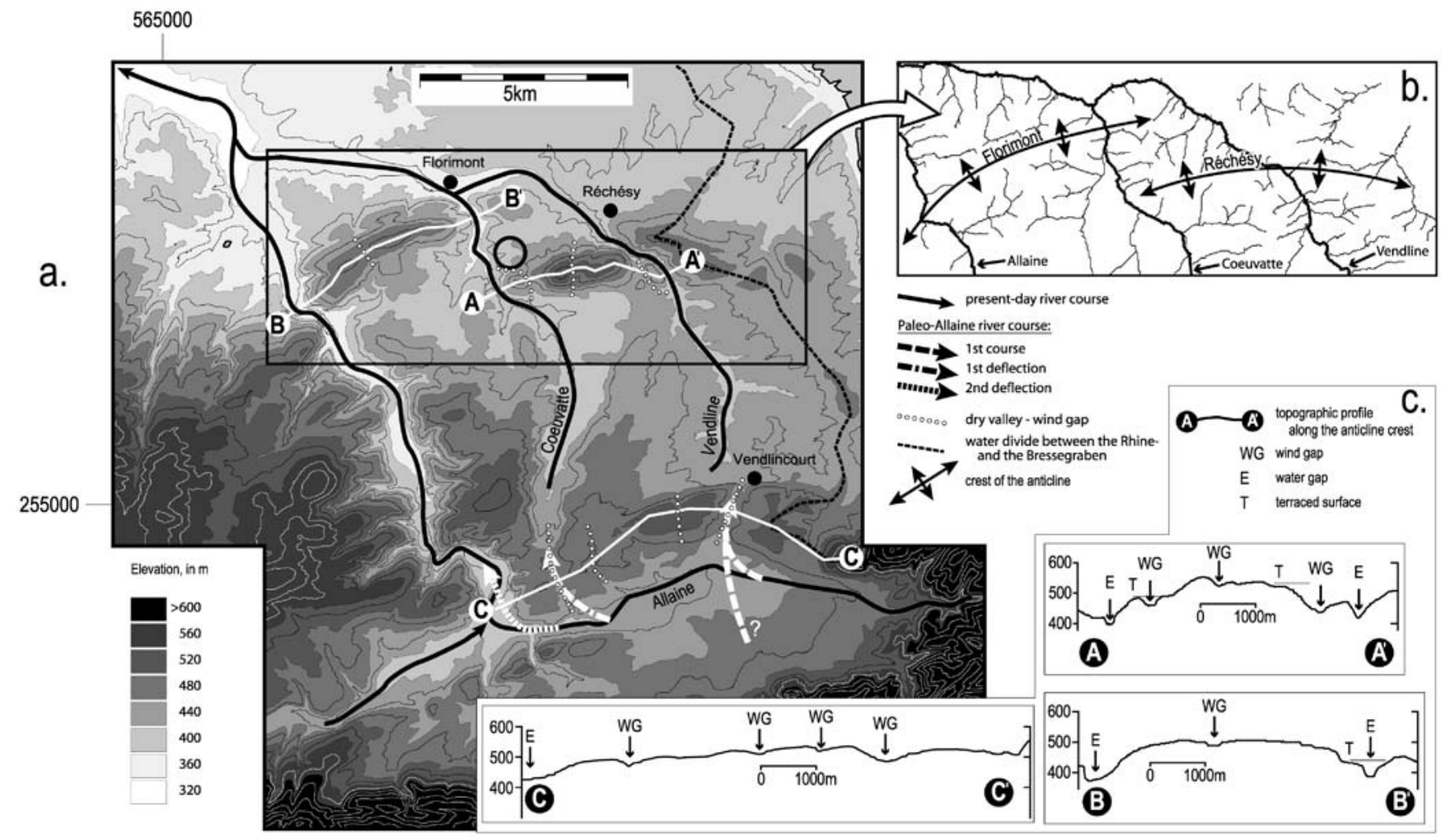

Fig. 9 a Topographic features in the northern Ajoie. Dashed white lines show traces of the profiles $A$ and $B$ indicated in c). Inserted rectangle indicates position of the drainage map. b Drainage map and sketched fold crests of the Florimont and the Réchésy anticlines

River. This again indicates abandonment of old valleys due to young uplift.

Although the relief of the arcuate Florimont anticline (Fig. 9) appears roughly symmetric, the associated drainage system is asymmetric. The northern limb is characterised by an annular valley system, individual dry valleys being separated by saddles (Fig. 9a and b). However, the upper course of these transverse valleys is oriented parallel to the axis of the anticline. These upper valley segments possibly represent remnants of an ENE-WSWtrending paleo-river (paleo-Vendline), which was forced to the north due to uplift of the anticlines crest. At the western and eastern plunging ends of the Florimont anticline hints of a radial drainage system are again recognizable (Fig. 9b). To the west this system was later captured by the young, consequent course of the Allaine River. The Allaine was deflected at this place due to uplift of the anticline. To the east, the antecedent Coeuvatte River, flowing in a gorge, cuts across the growing structure. At this point entrenching due to uplift is documented by an erosional terrace surface (Profile B-B' in Fig. 9). A small wind gap situated 2,000 m northeast of the present-day Allaine valley indicates that a minor paleo-stream crossed the present-day water divide.

\section{Synthesis}

Topographic profiles along the crest of the anticlines (Fig. 9c), reveal a decrease in wind gaps elevations in the direction of fold plunge. This implies lateral propagation of the anticlines, as demonstrated by Jackson et al. (1996) and Burbank et al. (1996). This, combined with the present-day drainage pattern, allows for the synthesis of the tectonic and morphological evolution of the area.

Prior to the growth of the Réchésy and Florimont anticlines, most of the drainage of the Ajoie south of them was directed northward across the area occupied by the present-day Vendlincourt anticline (Fig. 9), which is another post-"Sundgau gravel" anticline of the same generation, previously studied by Meyer et al. (1994). This anticline is also characterised by the occurrence of wind gaps (Profile C-C' in Fig. 9). This system probably represented a tributary catchment to the Middle Pliocene "Sundgau" paleo-Aare river (Fig. 4b). The eastern wind gap on the Vendlincourt anticline (Profile C-C' in Fig. 9) demonstrates that a first river course flowed to the north through the present-day Vendline valley. This course was afterwards diverted by the growing Vendlincourt anticline. Therefore, the paleo-Allaine river began to cross the area of the present-day Réchésy anticline west of the gorge formed by the present-day Vendline, as documented by the wind gaps at the culmination of the Réchésy anticline, facing the present-day Coeuvatte upstream valley, and that one further west ("paleo-Allaine river 
1st course" in Fig. 9). Consequently, the Vendlincourt anticline developed slightly before the Réchésy anticline. As the Réchésy anticline developed, minor S-N flowing tributary streams have been disrupted and diverted in the propagation direction of the growing anticline and incorporated into the main drainage branch of the paleoAllaine. As a result, the drainage basin of the paleoAllaine increased, until stream power was sufficient to maintain its position at the western nose of the Réchésy anticline, where propagation did not yet occur. As documented by the wind gap near the western termination of the Réchésy anticline and due to its growth, the diversion of the paleo-Allaine river (=present Coeuvatte River) led to an enlargement of the catchment area, which produced the incision of the water gap at the western termination of the Réchésy anticline first, and then the present-day water gap (Fig. 9).

As a next step, the Coeuvatte valley was cut off from the paleo-Allaine river by the westward propagation of the Vendlincourt fold. Growth of the Vendlincourt structure caused further westward diversion of the Allaine River ("paleo-Allaine river 2nd deflection" in Fig. 9), as suggested by Meyer et al. (1994).

The Allaine probably crossed the Florimont fold as an antecedent river. The enlargement of its catchment area due to the growth of the Vendlincourt anticline led to an increase in stream power, which resulted in the incision of a deep gorge (western water gap in Profile B-B' in Fig. 9). In contrast, the single small wind gap at the culmination of the Florimont anticline was formerly occupied by a minor stream, which had insufficient power to maintain its course across the rising anticline.

The controlling mechanism for the evolution of the drainage network can be mostly referred to the local tectonic movements in northern Ajoie. In fact, the regional and local base level, i.e. the Bressegraben and the downstream Doubs valley (Fig. 4) were subjected to uplift during Quaternary (Rat 1978; Sissingh 1998). No significant base level lowering, generating enhanced backward erosion and a control on the drainage system, occurred. Furthermore, the adjacent area to the north of the study area, which belongs to the same catchment area as the northern Ajoie, reveals a very mature relief with less erosional forms (Giamboni et al. 2004). Only the eastern part of the southern Rhinegraben, included in the Rhine River catchment area, was strongly affected by regional base lowering in the southern and northern Upper Rhinegraben (Giamboni et al. 2003).

Concluding, the origin of terraced dry valleys, wide wind gaps and entrenched water gaps observed at the Réchésy and Florimont anticlines as well as the evolution of the paleo-Allaine river are to be referred to the young uplift of the anticlines in the northern Ajoie.

\section{Summary and discussion}

The tectonic history of the area at the boundary between the southern Rhinegraben and Tabular Jura, from Late
Eocene to recent times, comprises four tectonic episodes. Each of them is characterised by a particular kinematic scenario. Their timing is constrained by structural and stratigraphic evidence.

The first episode (Fig. 10a) corresponds to the contemporaneous opening of the southern Rhinegraben and the Bressegraben (Illies 1977), and took place under regionally WNW-ESE-oriented extension from Priabonian to Early Aquitanian times (Illies 1977). Thereby, the sinistral Rhine-Bresse Transform Zone, which linked the two grabens, formed along pre-existing crustal discontinuities inherited from Variscan orogeny (Laubscher 1970). These pre-existing structures in the basement were reactivated with sinistrally transtensive wrench movements. Accommodation of these movements within the Mesozoic sedimentary cover occurred by formation of numerous ENE- to NNE-striking normal faults and E-W-striking flexures (Fig. 1). Related subsidence is documented by the onlap of Tertiary strata onto the flexures, marking a prominent unconformity. (Figs. 6, 7, $8,10 a)$.

A second unconformity, between Paleogene Rhinegraben fill and base of Middle Miocene sediments, documents a drastic change in the geodynamic setting. Due to the arrival of the northward migrating Alpine forebulge, presumably in Early Neogene times (Laubscher 1987, 1992), the entire southern Rhinegraben and adjacent areas became part of the immediate Alpine foreland. This is reflected in a change of the regional stress pattern from a vertical s1 and a WNW-ESE-trending s3 (extension) to a horizontal NNW-SSE-trending s1 (compression) (Larroque et al. 1987; Larroque and Laurent 1988). This change was accompanied by large-scale uplift and southward tilting of the southern Vosges-Black Forest dome together with the southern Rhinegraben, subjecting them to erosion. It found its sedimentary response in the deposition of the Middle Miocene fluviatile Bois de Raube (Kälin 1997 and Fig. 10b) and Juranagelfluh Formations (e.g. Buxtorf and Koch 1920; Laubscher 1961; Diebold et al. 1992; Kälin 1997). Locally, these Middle Miocene deposits reveal canyon-like entrenching. Existence and extent of a first (Early Miocene) transpressional reactivation of Eo-/Oligocene structures along the southern Rhinegraben margins remain speculative (Fig. 10b and Laubscher 2001).

A third tectonic episode postdates the deposition of the Bois de Raube and Juranagelfluh Formations (minimum age $10.5 \mathrm{Ma}$, Kälin 1997). On a more regional scale, the southernmost part of the Rhinegraben, which comprises the Delémont and Laufen basins (Fig. 1), now became involved in the "classical" thin-skinned folding and thrusting of the Jura Mountains. The exact location of the northern edge of the thin-skinned wedge is well constrained only southeast of Basel, i.e. at the boundary between the Folded and the Tabular Jura, and in the southernmost Ajoie, south of Porrentruy (Fig. 1). Style (thin- vs. thick-skinned) and age of folding in an intermediate area (Ferrette and the Blauen anticlines, see Fig. 1) remain a matter of debate (see below). 
Fig. 10 Sketches of the evolution of the northern Ajoie flexural folds developed at the boundary between the Tabular Jura and the southern Rhinegraben. Black arrows illustrate major tectonic events. a Subsidence during Priabonian to

Early Aquitanian in connection with Rhinegraben formation. b Regional uplift during Late Aquitanian to Early Burdigalian times, followed by the deposition of Middle Miocene sediments. c Gentle folding during Late Miocene to Early Pliocene, simultaneous with the main phase of thin-skinned deformation in the southerly adjacent Jura mountains. d Local planation followed by the deposition of the Sundgau gravel. e Post 2.9 Ma folding, related to inversion/reactivation of Paleozoic basement faults. Figure is not to scale

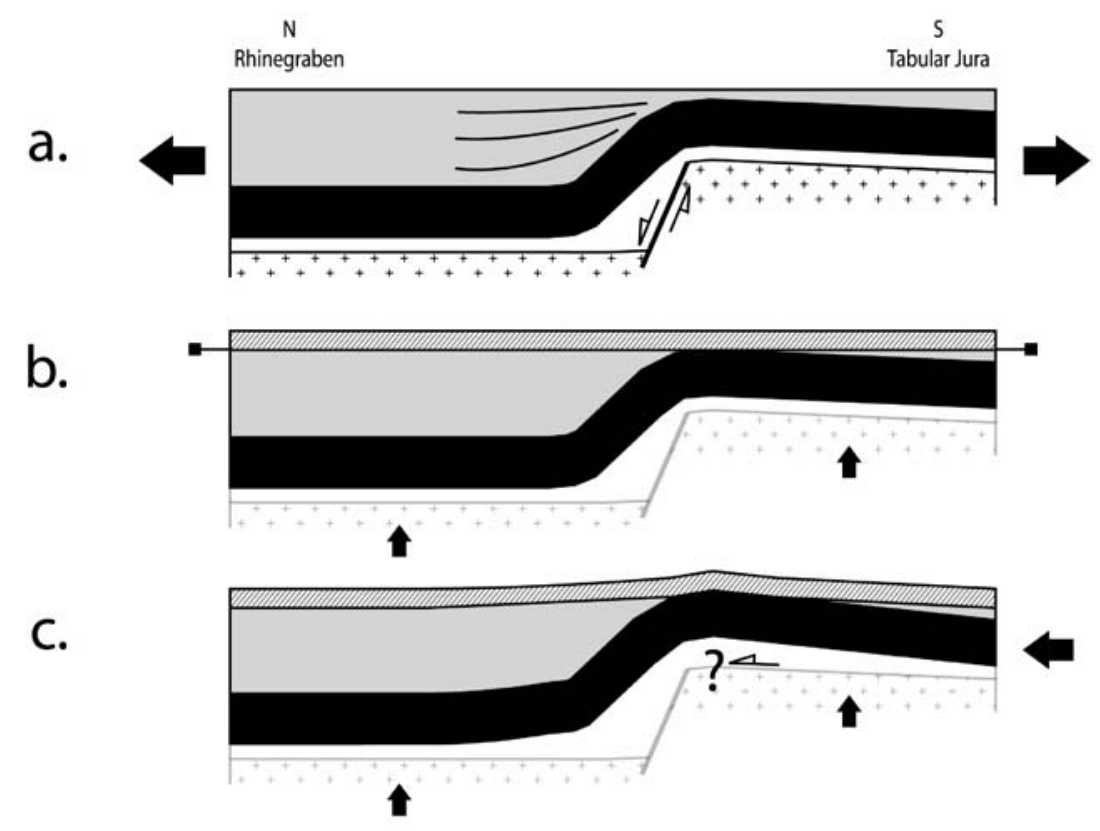

d.

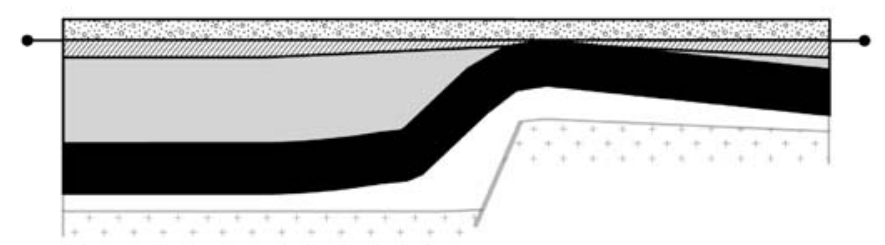

e.

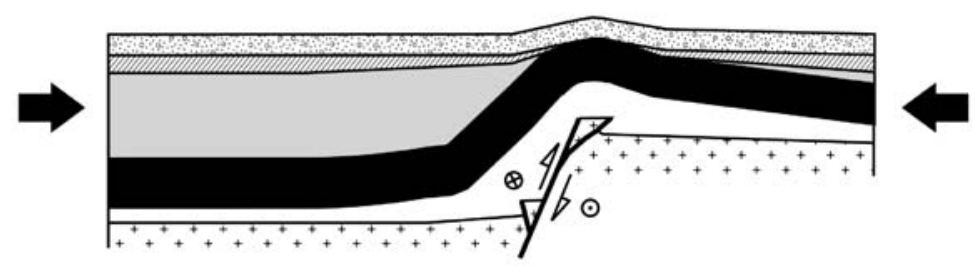

The fourth and youngest episode is associated with the unconformable deposition of the "Sundgau gravel" (Fig. 10d) and its subsequent folding (Figs. 5, 7, 10e). The thick-skinned origin of this deformation is indicated by zones of intensively faulted Permo-Carboniferous strata, above which the pronounced up-warping of Mesozoic strata points to the existence of positive flower structures (Fig. 7). Due to this reactivation, former flexures of purely extensional origin became shortened and now form gentle anticlines, traceable at the surface by contouring the folded base of the Pliocene gravel. At least part of the shortening in the Ferrette anticline, hitherto considered to have a purely thin-skinned origin (e.g. Fischer 1965), occurred during this fourth episode of thick-skinned deformation (Fig. 5).

Paleostress trajectories, derived from fault plane data along the folded northern margin of the Jura, in the vicinity of the en-échelon aligned anticlines, and accordingly attributed to the post-Pliocene episode of folding of the sedimentary skin, reveal N-S- to NW-SE-trending s1directions (Ustaszewski et al. 2001). This agrees with maximum horizontal stress directions, inferred from in- 
situ stress measurements, performed in the Jura Mountains (Becker 2000) and southern Rhinegraben (Häring 2001). However, focal plane mechanisms of recent earthquakes reveal NW-SE-trending directions of maximum horizontal stress and dominantly strike-slip (but not reverse) faulting in the seismogenic basement (e.g. Plenefisch and Bonjer 1997; Deichmann et al. 2000). The reasons for this discrepancy are yet unknown. Strain partitioning in the transpressively reactivated RhineBresse Transform Zone, allowing for the accommodation of strike-slip faulting and thrusting at different locations in basement and cover, is one possibility.

Geomorphological analysis allowed for a reconstruction of stream diversions and changes in the drainage pattern of the Ajoie and the south-westernmost part of the Rhinegraben. The drainage system in the area of the Réchésy, Florimont and Vendlincourt folds has recorded information on the growth of these folds and interactions with the evolving hydrosystem. These changes occurred in response to active uplift and postdate the deposition of the "Sundgau gravel" (post $2.9 \mathrm{Ma}$ ). Hence, the presentday drainage system formed during Late Pliocene to Pleistocene times. Ongoing tectonic activity is expected, as shown by complementary studies in the Sundgau area north of the study area (Nivière and Winter 2000; Giamboni et al. 2003). Disruption and displacement of the Allaine river catchment confirm the young age (postSundgau gravel) of the Vendlincourt anticline previously inferred by Meyer et al. (1994). Furthermore, structures such as wind gaps formed early are useful to reconstruct the evolution of the catchment areas and the changes in stream power of paleo-river systems.

The basic observations derived from geophysical, structural and seismotectonic analysis clearly indicate that within the prevailing stress field in the Western European plate (overall NW-SE-oriented maximum horizontal stresses) dextral transpressive reactivation of basement faults in the Paleogene Rhine-Bresse transform zone might very well explain both the en-échelon alignment of some observed anticlines (Fig. 5) and the basement-rooted earthquake foci with predominant strikeslip mechanisms.

\section{Conclusions}

The deformation of the Pliocene Sundgau gravel indicates neotectonic activity in the southern Rhinegraben. Furthermore, the present-day drainage system stores informations on the evolving folding, suggesting an ongoing tectonic activity. Reflection seismic data reveal that enéchelon anticlines at the surface are related to thickskinned inversion of ENE- to NNE-striking basement faults within the Rhine-Bresse transform zone, contradicting the often invoked thin-skinned tectonism in the southern Rhinegraben. The paleostress trajectories attributed to the post-Pliocene episode are consistent with the present day stress field, which depicts a N-Sto NW-SE- orientation of the maximum horizontal stress.
Moreover, focal plane mechanisms of recent earthquakes dominantly reveal NW-SE-oriented directions of maximum horizontal stress and strike-slip faulting in the seismogenic basement. These settings allow the ENEstriking Paleozoic basement faults to be reactivated in a dextral transpressive way. NNE-oriented faults are reactivated as sinistral strike-slip faults. However, stress decoupling favoured by the presence of a décollement layer between the basement and the cover, leads to accommodation of predominantly strike-slip faulting in the basement as well as thrusting and folding in the cover.

Acknowledgements This paper is a contribution to both the EUCOR-URGENT (Upper Rhine Graben Evolution and Neotectonics) and ENTEC (Environmental tectonics) projects. The authors thank Shell International EP for authorisation to publish their seismic data and P. Elsass, BRGM Alsace, for authorisation to publish the geoelectric data. Financial support for K. U. from Swiss grant BBW 99-0567-1 and for M.S. by a University of Basel ELTEM grant is kindly acknowledged. The manuscript substantially benefited from thorough and constructive reviews by $\mathrm{G}$. Bertrand (Freiburg) and T. Winter (Orléans).

\section{References}

Allenbach R (2001) Synsedimentary tectonics in an epicontinental sea: a new interpretation of the Oxfordian basins of northern Switzerland. Eclogae Geol Helv 94(3):265-287

Allenbach R (2002) The ups and downs of "Tectonic Quiescence"-recognizing differential subsidence in the epicontinental sea of the Oxfordian in the Swiss Jura Mountains. Sediment Geol 150:323-342

Allenbach R (2003) Spatial patterns of Mesozoic facies relationships and the age of the upper Rhinegraben Lineament. Int $\mathrm{J}$ Earth Sci (in revision)

Allia V (1996) Sedimentologie und Ablagerungsgeschichte des Opalinustons in der Nordschweiz. Dissertation am GeologischPaläontologischen Institut der Universität Basel, Basel, 185 pp

Becker A (2000) The Jura Mountains-an active foreland fold-andthrust belt? Tectonophysics 321:381-406

Berger J P (2000) Chronostratigraphic chart for the South and North Jura Molasse, the South Rhine Graben, the North Rhine Graben and the Mainzer Becken. http://compl.geol.unibas.ch/ groups/3_3/3_3Main.htm

Bergerat F, Chorowicz J (1981) Etude des images Landsat de la zone transformante Rhin-Sa(France). Geol Rundsch 70(1):354 367

Bergerat F, Mugnier J-L, Guellec S, Truffert C (1990) Extensional tectonics and subsidence of the Bresse basin: an interpretation from Ecors data. In: Roure F, Heitzmann P, Polino R (eds) Deep structures of the Alps. vol 1, vol spec Soc Geol Ital, Mémoire de la Société géologique de la Suisse, Zh, pp 145-156

Berner P (2001) Kartierung Sundgau/Ajoie 2000. Diplomarbeit am Geologisch-Paläontologischen Institut der Universität Basel, Basel, 19 pp

Bitterli-Brunner B, Fischer H, Herzog P (1984) Geologischer Atlas der Schweiz 1:25000 - Blatt 80: Arlesheim-mit Erläuterungen. Geologische Kommission der Schweiz. Naturf. Ges., $1 / 25000$

Bolliger T, Engesser B, Weidmann M (1993). Première découverte de mammifères pliocènes dans le Jura Neuchâtelois. Eclogae Geol Helv 86:1031-1068

Bonvalot J (1974) Les cailloutis de la Forêt de Chaux (Jura): leurs rapports avec les matériaux détritiques de Sundgau et du Nord de la Bresse, Université de Dijon, Dijon, 89 pp

Brianza M, Hauber L, Hottinger L, Maurer H (1983) Die geologischen Resultate der Thermalwasserbohrung von Leymen 
(Haut-Rhin, Frankreich) sch von Basel, unter besonderer Berichtigung der Schwerminerale. Eclogae Geol Helv 76(1): 253-279

Burbank D, Meigs A, Brosovic N (1996) Interactions of growing folds and coeval depositional systems. Basin Res 8:199-223

Burkhalter R M (1996) Die Passwang-Alloformation (unteres Aalénien bis unteres Bajocien) im zentralen und nichen Schweizer Jura. Eclogae Geol Helv 89:875-934

Buxtorf A (1901) Geologie der Umgebung von Gelterkinden. Beitr geol Karte Schweiz 11

Buxtorf A, Koch R (1920) Zur Frage der Pliocaenbildungen im nordschweizerischen Juragebirge. Verh Natf Ges Basel 31:113132

Contini D, Kuntz G, Angély B, Laffly J L, Kerrien Y, Landry J, Théobald N (1973) Carte Géologique et Notice ExplicativeFeuille 3522 Montbéliard. BRGM, Orleans, 1/50000

Debrand-Passard S, Courbouleix S (1984) Synthèse géologique du sud-est de la France. Mém BRGM 125-126:1-615

Deichmann N, Ballarin Dolfin D, Kastrup U (2000) Seismizität der Nord- und Zentralschweiz. Nagra Tech. Ber. NTB 00-05, Nagra, Wettingen, 93pp

Diebold P (1990) Die tektonische Entwicklung der Nordschweiz. Nagra Informiert 2/90:47-55

Diebold P, Naef H (1990) Der Nordschweizer Permokarbontrog. Nagra Informiert 2/90:29-36

Diebold P, Noack T (1997) Late Palaeozoic troughs and Tertiary structures in the eastern Folded Jura. In: Pfiffner OA, Lehner E, Heitzmann P, Mueller S, Steck A (eds). Deep structure of the Swiss Alps: results of the NRP 20. Birkhäuser, Basel, pp 59-63

Diebold P, Naef H, Ammann M (1992) Zur Tektonik der zentralen Nordschweiz-Interpretation aufgrund regionaler Seismik, Oberflächengeologie und Tiefbohrungen. Nagra Tech. Ber. NTB 90-04, Nagra, Wettingen

Doebl F (1970) Die tertiären und quartären Sedimente des schen Rheingraben. In: Illies JH, Mueller S (eds). Graben problems. Schweizerbart, Stuttgart, pp 56-66

Doebl F, Teichmr R (1979) Zur Geologie und heutigen Geothermik im mittleren Oberrhein-Graben. Fortschr Geol Rheinl Westfalen $27: 1-27$

Duringer P (1988) Les conglomérats des bordures du rift cénozoïque rhénan. Dynamique sédimentaire et contrôle limatique. $\mathrm{PhD}$ Thesis, Université. Pasteur, Strasbourg, 278 pp

Erzinger E (1943) Die Oberflächenformen der Ajoie (Berner Jura). Mitteilungen der geogr.-ethnologischen Gesellschaft in Basel 6:1-138

Fabbri O, Gaviglio P, Marquer D (2001) Palaeotectonic and neotectonic analyses in the Rhine-Bresse Transfer Zone: insights and perspectives from preliminary studies in the Besançon and Massif de la Serre areas. In: Dèzes P (ed) 2nd EUCOR-URGENT Workshop, October 7-11th 2001. Mont Saint-Odile Strasbourg (France), $36 \mathrm{pp}$

Fejfar O, Heinrich W-D, Lindsay EH (1998) Updating the Neogene rodent biochronology in Europe. Mededelingen Nederlands Instituut voor Toegepaste Geowetenschappen TNO 60:533-554

Fischer H (1965) Geologie des Gebietes zwischen Blauen und Pfirter Jura. Beitr geol Karte Schweiz NF 122:107

Fischer H (1969) Geologischer Überblick über den südlichen Oberrheingraben und seine weitere Umgebung. Regio Basiliensis 10(1):57-84

Giamboni M, Schneider B, Wetzel A (2004) Geomorphic response of alluvial rivers to active tectonics: example from the southern Rhinegraben. Z f Geomorphologie (submitted)

Giamboni M, Wetzel A, Schumacher M (2003) Plio-Pleistocene folding in the southern Rhinegraben recorded by the evolution of the drainage network. Eclogae Geol Helv (accepted)

Gonzalez R, Wetzel A (1996) Stratigraphy and paleogeography of the Hauptrogenstein and Klingnau Formations (middle Bajocian to late Bathonian), northern Switzerland. Eclogae Geol Helv 89:695-720

Häring M (2001) Horizontale Hauptspannung im Grundbgebirge. http://www.geothermal.ch
Hummel KL (1914) Die Tektonik des Elsgaues (Berner Tafeljura). Berichte der Naturforschenden Gesellschaft zu Freiburg i.Br. 20:1-82

Illies JH (1977) Ancient and recent rifting in the Rhinegraben. Geol En Mijinbouw 56(4):329-350

Illies JH, Greiner G (1979) Holocene movements and state of stress in the Rhinegraben rift system. Tectonophysics 52:349-359

Jackson J, Norris R, Youngson J (1996) The structural evolution of active fault and fold systems in central Otago, New Zealand: evidence revealed by drainage patterns. J Struct Geol 18(2/ 3):217-234

Jordan P, Nüesch R (1989) Deformation structures in the Muschelkalk anhydrites of the Schafisheim Well (Jura overthrust, northern Switzerland). Eclogae Geol Helv 82(2):429-454

Kälin D (1993) Stratigraphie und Säugetierfaunen der Oberen Sassermolasse der Nordwestschweiz. ETHZ, Zh, 238 pp

Kälin D (1997) Litho- und Biostratigraphie der mittel- bis obermiozänen Bois de Raube-Formation (Nordwestschweiz). Eclogae Geol Helv 90:97-114

Keller EA, Pinter N (2002) Active tectonics: earthquakes, uplift and landscape. Prentice Hall, Upper Saddle River, 362 pp

Koch R (1923) Geologische Beschreibung des Beckens von Laufen im Berner Jura. Beitr geol Karte Schweiz NF 48(2. Abt.):61

Krohe A (1996) Variscan tectonics of central Europe: Postaccretionary intraplate deformation of weak continental lithosphere. Tectonics 15:1364-1388

Larroque JM, Laurent P (1988) Evolution of the stress field pattern in the south of the Rhine Graben from the Eocene to the present. Tectonophysics 148:41-58

Larroque JM, Etchecopar A, Philip H (1987) Evidence for the permutation of stresses s1 and s2 in the Alpine foreland: the example of the Rhine Graben. Tectonophysics 144:315-322

Laubscher H (1961) Die Fernschubhypothese der Jurafaltung. Eclogae Geol Helv 54(1):221-282

Laubscher H (1970) Grundsätzliches zur Tektonik des Rheingrabens. In: Illies $\mathrm{JH}, \mathrm{Mr} \mathrm{S}$ (eds) Graben problems. International Upper Mantle Projekt. Schweizerbart, Stuttgart, pp 79 87

Laubscher H (1982) Die Stecke des Rheingrabens-ein kinematisches und dynamisches Problem. Eclogae Geol Helv 75(1):101116

Laubscher $H$ (1986) The eastern Jura: relations between thinskinned and basement tectonics, local and regional. Geol Rundsch 75(3):535-553

Laubscher H (1987) Die tektonische Entwicklung der Nordschweiz. Eclogae Geol Helv 80(2):287-303

Laubscher H (1992) Jura kinematics and the Molasse Basin. Eclogae Geol Helv 85(3):653-675

Laubscher H (2001) Plate interactions at the southern end of the Rhine Graben. Tectonophysics 343:1-19

Laubscher H, Noack T (1997) The deep structure of the Basel Jura. In: Pfiffner OA, Lehner E, Heitzmann P, Mueller S, Steck A (eds) Deep structure of the Swiss Alps: results of the NRP 20. Birkhäuser, Basel, pp 54-58

Liniger H (1964) Beziehungen zwischen Pliozän und Jurafaltung in der Ajoie. Eclogae Geol Helv 57(1):75-90

Liniger H (1966) Das plio-altpleistozäne Flussnetz der Nordschweiz. Regio Basiliensis 7(2):158-177

Liniger H (1967) Pliozän und Tektonik des Juragebirges. Eclogae Geol Helv 60(2):407-490

Liniger H (1970) Geologischer Atlas der Schweiz 1:25000 - Blatt 55: Bonfol-mit Erläuterungen. Geologische Kommission der Schweiz Naturf Ges, 1/25000

Matter A (1987) Faziesanalyse und Ablagerungsmillieus des Permokarbons im Nordschweizer Trog. Eclogae Geol Helv 80:345-367

Ménillet F, Coulon M, Fourquin C, Paicheler J-C, Lougnon J-M, Lettermann M (1989) Carte Géologique et Notice Explicative Feuille 3620 Thann. BRGM, Orleans, 1/50000

Meyer B, Lacassin R, Brulhet J, Mouroux B (1994) The Basel 1356 earthquake: which fault produced it? Terra Nova 6:54-63 
Miall A (1996) The geology of fluvial deposits: sedimentary facies, basin analysis and petroleum geology. Springer, Berlin Heidelberg New York, 582 pp

Müller W H, Blümling P, Becker A, Clauss B (1987) Die Entkoppelung des tektonischen Spannungsfeldes an der JuraÜberschiebung. Eclogae Geol Helv 80(2):473-489

Müller WH, Naef H, Graf HR (ed) (2001) Geologische Entwicklung der Nordschweiz, Neotektonik und Langzeitszenarien, Zer Weinland. NAGRA Technischer Bericht, 99-08. NAGRA, Wettingen, $226 \mathrm{pp}$

Nivière B, Winter T (2000) Pleistocene northwards fold propagation of the Jura within the southern Upper Rhine Graben: seismotectonic implications. Glob Planet Change 27:263-288

Petit C, Campy M, Chaline J, Bonvalot J (1996) Major palaeohydrographic changes in Alpine foreland during the PliocenePleistocene. Boreas 25:131-143

Pfiffner OA, Erard PF, Stäuble M (1997) Two cross sections through the Swiss Molasse Basin. In: Pfiffner OA, Lehner E, Heitzmann P, Mueller S, Steck A (eds) Deep structure of the Swiss Alps: results of the NRP 20. Birkhäuser, Basel, pp 59-63

Pflug R (1982) Bau und Entwicklung des Oberrheingrabens. Wissenschaftliche Buchgesellschaft Darmstadt-Erträge der Forschung 184:1-145

Philippe Y (1995) Rampes latérales et zones de transfert dans les chaînes plissées: géometrie, conditions de formation et pièges structuraux associés. PhD Thesis, Savoie, $272 \mathrm{pp}$

Plenefisch T, Bonjer K-P (1997) The stress field in the Rhine Graben area inferred from earthquake focal mechanism and estimation of frictional parameters. Tectonophysics 275:71-97

Rat P (1978) Les phases tectoniques au Tertiaire dans le Nord du Fossé bressan et ses marges bourguignonnes en regard des systèmes d'erosin et de sédimentation. C R Soc géol France:26-28

Ruhland M, Blanat J G (1973) Carte Géologique et Notice Explicative-Feuille 3722 Ferrette - 1/50000. BRGM, Orléans

Schumacher ME (2002) Upper Rhine Graben: role of pre-existing structures during rift evolution. Tectonics 21(1):10.1029/ 2001TC900022 (6-1-6-17)

Schumm A (1985) Patterns of alluvial rivers. Annu Rev Earth Planet Sci 13:5-27

Schumm SA (1986) Alluvial river response to active tectonics. In: Council NR (ed) Active tectonics. National Academy Press, Washington, DC, pp 80-94
Seeber L, Gornitz V (1983) River profiles along the Himalayan arc as indicators of active tectonics. Tectonophysics 92:335-367

Sissingh W (1998) Comparative Tertiary stratigraphy of the Rhine Graben, Bresse Graben and Molasse Basin: correlation of Alpine foreland events. Tectonophysics 300:249-284

Sittler C (1972) Le Sundgau, aspect géologique et structural. Bull Sci géol 25:93-118

Théobald N (1934) Les alluvions du Pliocène supérieur de la région du Sundgau. Bull Soc Ind Mulhouse 101:1-36

Théobald N, Devantoy J (1963) Carte Géologique de la France et Notice Explicative-Feuille 3621 Belfort. BRGM, Orleans, $1 / 50000$

Théobald N, Dubois G, Goguel J (1958) Carte Géologique de la France et Notice Explicative-Feuille 3721 Altkirch-Huningue. BRGM, Orleans, 1/50000

Théobald N, Schweitzer M, Hudeley H (1976) Carte Géologique de la France et Notice Explicative-Feuille 3820 Mulhouse. Belfort. BRGM, Orleans, 1/50000

Thury M, Gautschi A, Mazurek M, Mr W H, Naef H, Pearson F J, Vomvoris S, Wilson W (1994) Geology and hydrogeology of the crystalline basement of Northern Switzerland. Nagra Tech. Ber. NTB 93-01, Nagra, Wettingen, 452 pp

Ustaszewski K, Schmid SM, Giamboni M (2001) The frontal folds of the Jura mountains revisited: subsequent folding of Oligocene extensional structures during a thick-skinned phase of Jura folding? J Conf Abstr 6(1):630

Wetzel A, Allenbach R, Allia V (2002) Reactivated basement structures affecting the sedimentary facies in a tectonically "quiescent" epicontinental basin: an example from NW Switzerland. Sediment Geol 157:153-172

Ziegler PA (1990a) Collision related intra-plate compression deformations in Western and Central Europe. J Geodyn $11: 357-388$

Ziegler PA (1990b) Geological atlas of Western and Central Europe. Shell Internationale Petroleum Maatschappij BV, The Hague, $238 \mathrm{pp}$

Ziegler PA (1992) European Cenozoic rift system. Tectonophysics 208:91-111

Ziegler PA, Cloetingh S, Van Wees J-D (1995) Dynamics of intraplate compressional deformation: the Alpine foreland and other examples. Tectonophysics 252:7-59 